\title{
Compositional and Functional Properties of Buttermilk: A Comparison Between Sweet, Sour, and Whey Buttermilk ${ }^{1}$
}

\author{
I. Sodini, ${ }^{*}$ P. Morin, $\dagger$ A. Olabi, $\neq$ and R. Jiménez-Flores ${ }^{\star 2}$ \\ *Dairy Products Technology Center, California Polytechnic State University, San Luis Obispo 93407 \\ †Centre de Recherche STELA, Université Laval, Ste-Foy, Québec G1K7P4, Canada \\ ‡Department of Food Science and Nutrition, California Polytechnic State University, San Luis Obispo 93407
}

\section{ABSTRACT}

Buttermilk is a dairy ingredient widely used in the food industry because of its emulsifying capacity and its positive impact on flavor. Commercial buttermilk is sweet buttermilk, a by-product from churning sweet cream into butter. However, other sources of buttermilk exist, including cultured and whey buttermilk obtained from churning of cultured cream and whey cream, respectively. The compositional and functional properties (protein solubility, viscosity, emulsifying and foaming properties) of sweet, sour, and whey buttermilk were determined at different $\mathrm{pH}$ levels and compared with those of skim milk and whey. Composition of sweet and cultured buttermilk was similar to skim milk, and composition of whey buttermilk was similar to whey, with the exception of fat content, which was higher in buttermilk than in skim milk or whey ( 6 to $20 \%$ vs. 0.3 to $0.4 \%$ ). Functional properties of whey buttermilk were independent of $\mathrm{pH}$, whereas sweet and cultured buttermilk exhibited lower protein solubility and emulsifying properties as well as a higher viscosity at low $\mathrm{pH}(\mathrm{pH}$ $\leq 5$ ). Sweet, sour, and whey buttermilks showed higher emulsifying properties and lower foaming capacity than milk and whey because of the presence of milk fat globule membrane components. Furthermore, among the various buttermilks, whey buttermilk was the one showing the highest emulsifying properties and the lowest foaming capacity. This could be due to a higher ratio of phospholipids to protein in whey buttermilk compared with cultured or sweet buttermilk. Whey buttermilk appears to be a promising and unique ingredient in the formulation of low $\mathrm{pH}$ foods.

Key words: buttermilk, whey buttermilk, functional properties

\footnotetext{
Received January 14, 2005.

Accepted August 8, 2005.

${ }^{1}$ Use of names, names of ingredients, and identification of specific models of equipment is for scientific clarity and does not constitute any endorsement of product by authors, California Polytechnic State University (San Luis Obispo) or the Dairy Products Technology Center.

${ }^{2}$ Corresponding author: rjimenez@calpoly.edu
}

\section{INTRODUCTION}

Buttermilk is the aqueous phase released during the churning of cream in butter manufacture. It contains all the water-soluble components of cream such as milk protein, lactose, and minerals. It also encloses material derived from milk fat globule membrane (MFGM), which is disrupted during the churning and mostly migrates to the buttermilk fraction (Corredig and Dalgleish, 1997). Buttermilk contains more phospholipids than milk because of its high content in MFGM material, which is rich in phospholipids that constitute about one-third of the MFGM DM (Mulder and Walstra, 1974). For instance, Elling et al. (1996) reported 7 times more phospholipids in buttermilk than in whole milk, with concentrations equal to $0.89 \mathrm{mg} / \mathrm{g}$ and $0.12 \mathrm{mg} / \mathrm{g}$, respectively. Christie et al. (1987) determined a 4-fold increase of phospholipids in buttermilk compared with whole milk, with a phospholipid content of $0.72 \mathrm{mg} /$ $\mathrm{mL}$ and $0.15 \mathrm{mg} / \mathrm{mL}$, respectively. The high content of phospholipids in buttermilk makes this dairy ingredient interesting for use as a functional ingredient because of the emulsifying properties of phospholipids (Elling et al., 1996; Corredig and Dalgleish, 1998a; Wong and Kitts, 2003). In addition, phospholipids have been shown to possess biological activity. Some studies have demonstrated the anticarcinogenic potential of phospholipids, especially against colon cancer (Dillehay et al., 1994; Schmelz et al., 1996, 1998), as well as their protective effect against bacterial toxins and infection (Rueda et al., 1998; Sprong et al., 2002).

The overall production of liquid buttermilk is 4.1 million tons worldwide and 0.6 million tons in the United States, based on the annual production of butter from $40 \%$ cream (International Dairy Federation, 2002). In the United States, the commercial use of buttermilk is mainly for the baking industry (39\%), prepared dry mixes (33\%), and for the dairy industry (23\%) (International Dairy Foods Association, 2003). In the baking industry, buttermilk is used to improve flavor and texture of bakery products (Vetter, 1984). Other industrial uses of buttermilk are to prepare functional mixes for various foods, such as sauces, chips, and chocolate prod- 
ucts (Chandan, 1997). In the dairy industry, buttermilk is used in cheese making (Joshi et al., 1994), in formulation of ice cream (Chandan, 1997) or yogurt (Trachoo and Mistry, 1998), or in the manufacture of recombined milks (Singh and Tokley, 1990). A unique functionality reported in buttermilk is its ability to increase the heat stability of recombined milks (Singh and Tokley, 1990), mainly due to phospholipid-protein interactions preventing protein coagulation during sterilization (McCrae, 1999). It has also been demonstrated that addition of buttermilk in the manufacture of low-fat Cheddar can improve the texture of the cheese because of the high water-holding capacity of phospholipids (Raval and Mistry, 1999; Turcot et al., 2001). For all the applications, an important functional property of buttermilk is its emulsifying property (Elling et al., 1996; Corredig and Dalgleish, 1998a; Wong and Kitts, 2003). On the other hand, foaming capacity is significantly lower for buttermilk than for skim milk (Wong and Kitts, 2003), probably because of the antifoaming properties of the phospholipids when combined with proteins (Coke et al., 1990; Vaghela and Kilara, 1996).

Studies have been undertaken to assess and enhance the functional properties of buttermilk. Heat treatment applied to cream in butter manufacture has been shown to be detrimental to the functionality of buttermilk, because of denaturation of whey proteins and their interaction with MFGM (Corredig and Dalgleish, 1997, 1998b). Several physicochemical treatments have been applied to increase the concentration of phospholipids in buttermilk, such as microfiltration (Sachdeva and Buchheim, 1997; Astaire et al., 2003; Corredig et al., 2003; Morin et al., 2004), ultrafiltration (Sachdeva and Buchheim, 1997), super-critical fluid extraction (Astaire et al., 2003), eventually preceded by a preliminary treatment to remove the casein fraction (Sachdeva and Buchheim, 1997; Corredig et al., 2003).

Most of the work on the functionality of buttermilk as a food ingredient has been done with sweet buttermilk, which is the major source of commercial buttermilk. No study has yet been developed to diversify the sources of buttermilk and to evaluate the effect of this diversification on its functionality. However, other types of buttermilk can be produced from milk fat, as cultured buttermilk obtained from churning of cultured cream, in the manufacture of European-style butter; or whey buttermilk, from churning of whey cream, in manufacture of whey butter. These ingredients are produced in much smaller quantities compared with the volume of sweet buttermilk; however, their potential market should not been neglected. The potential market for whey buttermilk is significant based on the large volume of whey produced each year. Considering an average fat content of $0.13 \%$ in whey, 57,000 tons of liquid whey buttermilk could be produced each year in the United States, which would constitute $10 \%$ of the current volume of sweet buttermilk (National Agricultural Statistics Service, 2004).

The main objectives of this work were to assess the compositional and functional properties (solubility, viscosity, emulsifying and foaming properties) of sweet, sour, and whey buttermilk, and to evaluate the potential of nonconventional buttermilks (cultured and whey buttermilks) as food ingredients. In addition, the functional properties of the different buttermilks were compared with those of milk and whey.

\section{MATERIALS AND METHODS}

\section{Samples}

Seven different dairy ingredients were studied, including 1 commercial medium-heat skim milk powder (SMP), 1 commercial whey powder (WP), and 5 buttermilk powders (BM). Two buttermilk powders (BM1 and BM2) were commercial sweet buttermilks kindly provided by 2 Californian dairy companies; the 2 other buttermilk powders (BM3, BM4, and BM5) were manufactured on site at the plant of the Dairy Products Technology Center (DPTC), California Polytechnic State University (San Luis Obispo) from sweet cream, cultured cream, and whey cream, respectively. For each trial, 100 to $200 \mathrm{~L}$ of cream were churned. Sweet cream and whey cream were provided by Foster Farms (Modesto, CA) and Hilmar Cheese Company (Hilmar, CA), respectively. They were churned after a waiting period of $16 \mathrm{~h}$ at $4^{\circ} \mathrm{C}$. Cultured cream was produced at DPTC from sweet cream (Foster cream, Foster Farms). The cream was preheated at $20^{\circ} \mathrm{C}$, inoculated with $0.07 \%$ (wt/wt) commercial mesophilic culture Flora Danica (Chr. Hansen, Milwaukee, WI), then incubated at the same temperature for $16 \mathrm{~h}$, and finally churned. The final $\mathrm{pH}$ of cultured cream was $4.90 \pm 0.05$. The 3 creams (sweet, sour, and whey cream) were churned to butter using a continuous pilot-scale butter churn (Egli AG, Bütschwil, Switzerland). Buttermilk was recovered in a milk can after butter fines were removed by filtration through cheesecloth, then spray dried using a Niro Filterlab Spray Drier (Hudson, WI). The buttermilk production on site at DPTC was repeated twice, with 2 different lots of the 3 creams. For commercial samples, 2 different lots of powder were used.

\section{Compositional Analyses}

Nitrogen and Protein Determination. The levels of total nitrogen (TN), nitrogen soluble at $\mathrm{pH} 4.6(\mathbf{S N})$, and NPN were determined via the Kjeldahl method (AOAC, 1995). All measurements were carried out in 
duplicate. The total protein was calculated as $\mathrm{TN} \times$ 6.38. The NPN, expressed in protein equivalent, was calculated as NPN $\times 6.38$. The soluble protein at $\mathrm{pH}$ 4.6 was calculated as $(\mathrm{SN}-\mathrm{NPN}) \times 6.38$. The insoluble protein at $\mathrm{pH} 4.6$ was calculated as $(\mathrm{TN}-\mathrm{SN}) \times 6.38$. The protein profile was established by SDS-PAGE using precast gels with 4 to $20 \%$ gradient (Gradipore, Frenchs Forest, Australia). All samples were diluted to $3.3 \mathrm{mg} /$ $\mathrm{mL}$ of total protein with deionized water. One volume of sample was added to 1 volume of reducing buffer containing $59 \mathrm{mM}$ Tris- $\mathrm{HCl} \mathrm{pH} 6.8,24 \%$ glycerol, $2 \%$ SDS, 5\% 2- $\beta$-mercaptoethanol, and $0.01 \%$ bromophenol blue. A sample of $10 \mu \mathrm{L}$ of the mixture was loaded after boiling. Gels were stained with Coomassie Blue R-250 (BioRad, Hercules, CA). Proteins were identified according their molecular weight by comparison to protein standard (BioRad).

Determination of Moisture, Fat Content, Phospholipids, Ash, and Lactose. Moisture was determined by drying each sample for $5 \mathrm{~h}$ in a vacuum oven at $100^{\circ} \mathrm{C}$ (American Dairy Products Institute, 1990). Fat content was determined by the Mojonnier ether extraction method as described by Marshall (1992). Extracted lipids were then diluted to $10 \mathrm{mg}$ of lipids per $\mathrm{mL}$ with 1:2 chloroform methanol and kept in a freezer $\left(-20^{\circ} \mathrm{C}\right)$ until analysis. Phospholipids were analyzed by HPLC with an electro-evaporative light scattering detector as described in Morin et al. (2004). All reagents were electrophoresis or HPLC grade. Ash content was determined by ignition for $16 \mathrm{~h}$ at $550^{\circ} \mathrm{C}$ in an electric muffle furnace (AOAC, 1995). All measurements were carried out in triplicate. Content of lactose + lactic acid was calculated by difference [total solid - (total protein + fat + ash)] as proposed by Guzman-Gonzalez et al. (1999).

Determination of $\boldsymbol{p H}$. The $\mathrm{pH}$ of $4 \%$ protein (wt/ wt) reconstituted powder was determined using a $\mathrm{pH}$ meter $\Phi 34$ (Beckman, Fullerton, CA). Measurements were done in quadruplicate.

\section{Functional Properties}

The functional properties were determined at $4 \mathrm{pH}$ levels (initial normal $\mathrm{pH}, \mathrm{pH} 6, \mathrm{pH} \mathrm{5}$, and $\mathrm{pH} 4$ ), and at a defined and normalized protein concentration (2 to $5 \% \mathrm{wt} / \mathrm{wt}$ ), depending on the property tested, as recommended by Hall (1996).

Preparation of Samples. The dairy ingredients were dissolved in deionized water at room temperature for $1 \mathrm{~h}$. The $\mathrm{pH}$ of the solution was eventually adjusted to $\mathrm{pH} 6, \mathrm{pH} 5$, or $\mathrm{pH} 4$, using $1 M$ and $0.1 M \mathrm{HCl}$ or $\mathrm{NaOH}$ and waiting one additional hour for $\mathrm{pH}$ stability.

Solubility. Protein solubility was determined as described by Wong and Kitts (2003). Protein solutions (5\%
$\mathrm{TN}, \mathrm{wt} / \mathrm{wt}$ ) at different $\mathrm{pH}$ values were centrifuged at $12,000 \times g$ for $15 \mathrm{~min}$ at $25^{\circ} \mathrm{C}$. Supernatant liquid was analyzed for TN by the Kjeldahl method. Measures were done in triplicate.

Viscosity. The viscosity of $4 \%$ (wt/wt) protein solutions at $4 \mathrm{pH}$ levels was determined at $20^{\circ} \mathrm{C}$ with a control-stress rheometer (model SR5000; Rheometric Scientific Inc., Piscataway, NJ). The rheometer was equipped with a concentric cylinder device consisting of a cup (32-mm diameter) and a bob (29.5-mm diameter, 44.25-mm length). About $17 \mathrm{~mL}$ of protein solution was transferred into the cup of the rheometer and the bob was lowered until the whole bob surface was covered. Five minutes were allotted for the sample temperature to equilibrate to $20^{\circ} \mathrm{C}$ before each analysis. Steady stress sweep in the range 0.1 to $1 \mathrm{~Pa}$ was applied to the sample to obtain a flow curve in the shear rate range 0.1 to $100 \mathrm{~s}^{-1}$. Apparent viscosity (in $\mathrm{Pa} \cdot \mathrm{s}$ ) was determined at $50 \mathrm{~s}^{-1}$. Three replicates were performed and fresh sample was used for each replicate.

Emulsifying Properties. Emulsions were prepared with $40 \mathrm{~mL}$ of a $2 \%(\mathrm{wt} / \mathrm{wt}$ ) protein solution combined with $10 \mathrm{~mL}$ of corn oil (Mazola, Bestfoods, Englewood Cliffs, NJ) to form a $20 \%$ (vol/vol) emulsion at $4 \mathrm{pH}$ values. The emulsion was created using an Ultra-Turrax mixer (model T18, IKA Works, Wilmington, NC) for $2 \mathrm{~min}$ at 22,000 rpm at room temperature (Flanagan and Fitzgerald, 2002; Raymundo et al., 2002). Then, volume particle diameter size distributions were determined using a laser diffraction particle size analyzer (model LS230, Beckman Coulter, Miami, FL). The arithmetic mean of the diameter size was calculated for each distribution. The optical parameters (adsorption coefficient, refractive index) of the corn oil droplets for the measurements were determined by spectrophotometry (Spectra Max Plus spectrophotometer, Molecular Devices Corporation, Sunnyvale, CA), and refractometry (Abbe refractometer, Fisher Scientific, Pittsburgh, PA) as recommended by Michalski et al. (2001). The adsorption coefficient, Ka, was calculated as $2.6 \times 10^{-7}$. The refractive index measured was 1.473 . These values were used for calculation based on the Mie theory for the laser light-scattering techniques. Each measurement was performed in triplicate.

Foaming Properties. Fifty milliliters $\left(V_{S}\right)$ of a $4 \%$ (wt/wt) protein solution at $4 \mathrm{pH}$ values was blended for 3 min using a Ultra-Turrax mixer (IKA Works) at $18,000 \mathrm{rpm}$ and poured into a graduated cylinder. The initial volume of foam $\left(V_{F}\right)$ was recorded and the foam was then left undisturbed for $10 \mathrm{~min}$. The volume of liquid drained beneath the foam $\left(V_{D}\right)$ was measured. Foam capacity $(F C)$, expressed in milliliters of foam generated divided by milliliter of solution $\left(V_{I}\right)$, and foam stability $(F S)$, expressed in milliliters of liquid re- 
SODINI ET AL.

Table 1. Gross composition (\%) on a DM basis, and natural $\mathrm{pH}$ of the samples in this work ${ }^{1}$

\begin{tabular}{lllllll}
\hline Samples & Total N & Fats & Phospholipids & Ash & Lactose & $\mathrm{pH}^{2}$ \\
\hline Skim milk powder & $35.9^{\mathrm{a}}$ & $0.3^{\mathrm{c}}$ & $\mathrm{ND}^{3}$ & $8.0^{\mathrm{a}}$ & $55.8^{\mathrm{c}}$ & $6.39^{\mathrm{b}}$ \\
Whey powder & $13.3^{\mathrm{c}}$ & $0.4^{\mathrm{c}}$ & $\mathrm{ND}$ & $7.5^{\mathrm{abc}}$ & $78.8^{\mathrm{a}}$ & $5.58^{\mathrm{d}}$ \\
Buttermilk powders & & & & & \\
BM1 & $32.9^{\mathrm{a}}$ & $5.7^{\mathrm{bc}}$ & $1.29^{\mathrm{b}}$ & $7.6^{\mathrm{ab}}$ & $53.8^{\mathrm{c}}$ & $6.46^{\mathrm{b}}$ \\
BM2 & $33.1^{\mathrm{a}}$ & $7.2^{\mathrm{bc}}$ & $1.34^{\mathrm{b}}$ & $7.3^{\mathrm{abc}}$ & $52.4^{\mathrm{c}}$ & $6.59^{\mathrm{a}}$ \\
BM3 & $31.5^{\mathrm{ab}}$ & $13.1^{\mathrm{b}}$ & $1.27^{\mathrm{b}}$ & $6.7^{\mathrm{cd}}$ & $48.7^{\mathrm{d}}$ & $6.61^{\mathrm{a}}$ \\
BM4 & $27.8^{\mathrm{b}}$ & $22.3^{\mathrm{a}}$ & $1.15^{\mathrm{b}}$ & $6.2^{\mathrm{d}}$ & $43.7^{\mathrm{e}}$ & $5.39^{\mathrm{e}}$ \\
BM5 & $14.1^{\mathrm{c}}$ & $15.5^{\mathrm{ab}}$ & $1.87^{\mathrm{a}}$ & $7.0^{\mathrm{bc}}$ & $63.4^{\mathrm{b}}$ & $5.98^{\mathrm{c}}$ \\
\hline
\end{tabular}

${ }^{\mathrm{a}-\mathrm{e}}$ Means within a column not sharing a common superscript differ significantly $(P \leq 0.05)$.

${ }^{1}$ Samples: One commercial skim milk powder, one commercial whey powder, and 5 buttermilk (BM) powders. Three buttermilks were obtained from sweet cream (BM1, BM2, and BM3), one buttermilk sample was obtained from cultured cream (BM4), and one was obtained from whey cream (BM5). Two buttermilks were commercial (BM1 and BM2), and 3 were manufactured at a pilot-scale (BM3, BM4, and BM5).

${ }^{2} \mathrm{pH}$ was determined in a $4 \%$ protein solution.

${ }^{3} \mathrm{ND}=$ Not determined.

maining foamed after 10 min divided by milliliter of solution, were calculated using the following equations:

$$
F C=\frac{V_{F}}{V_{I}} \text { and } F S=\frac{\left(V_{I}-V_{D}\right.}{V_{I}}
$$

Each measurement was performed in triplicate.

\section{Statistical Analyses}

Results were evaluated statistically using Minitab 13.1 Software (Minitab Inc., State College, PA). A 2factor ANOVA with interaction was performed to determine the effects of both sample and $\mathrm{pH}$ on functional properties of dairy ingredient. Multiple comparison of means was performed using Tukey's pairwise comparison at an $\alpha$-level of $5 \%$.

\section{RESULTS AND DISCUSSION}

\section{Composition}

Gross Composition. Table 1 shows the gross composition on a DM basis and the $\mathrm{pH}$ of the different powders.

The protein content was slightly lower for buttermilk powders obtained from sweet cream (BM1, BM2, BM3) and cultured cream (BM4), than for skim milk powder (27.8 to $33.1 \%$ compared with $35.9 \%$ ). This has been reported in other studies (Surel and Famelart, 1995; Elling et al., 1996; O'Connell and Fox, 2000; Turcot et al., 2001; Scott et al., 2003). A small part of the protein fraction of the sweet cream remains in the butter after churning. On the other hand, the buttermilk obtained from whey cream (BM5) contained a much smaller amount of protein, $14 \%$, so less than half the protein content of the buttermilk was obtained from sweet cream. This was due to the lack of casein in the whey cream as compared with cream, yielding values of protein of 0.89 and $1.94 \%$, respectively (Morin et al., accepted). It should be noted that the level of protein in whey buttermilk was very similar to that observed in whey (13\%), which is consistent with the expectations of whey buttermilk resembling whey composition as opposed to regular buttermilk, which resembles skim milk in composition.

Differences were observed for the fat content among buttermilks. Commercial buttermilks BM1 and BM2 contained 6 to $7 \%$ fat, whereas the buttermilks produced at DPTC had higher lipid content (13 to $22 \%$ fat). The same observation was reported by Elling et al. (1996). This was due to the lack of fat removal process during the manufacture of buttermilk on site, which did not include a centrifugation step to remove the excess lipid, as used for commercial buttermilk. The centrifugation of the buttermilk was not performed on site because the quantity of buttermilk produced (50 to 100 L) was too low to allow the use of the pilot-plant centrifuge. On the other hand, skim milk powder and whey powders contained very little fat $(<0.5 \%)$ compared with commercial buttermilks ( $>5 \%)$. This low fat content has been reported by others (Surel and Famelart, 1995; Elling et al., 1996; Turcot et al., 2001) and is due to the presence of MFGM fractions, small milk fat globules, and free lipids not extractable by centrifugation (Corredig and Dalgleish, 1997).

Phospholipids content of the buttermilks showed similar composition according to their origin and place of manufacturing, except for whey buttermilk BM5. Although the phospholipids content is significantly higher in BM5, the fact that the ratio of phospholipids to protein is almost 3.5 times higher in this sample is even more striking. 
Table 2. Content of the nitrogen fraction of a commercial skim milk powder, a commercial whey powder, and 5 buttermilk powders ${ }^{1,2}$

\begin{tabular}{lccc}
\hline & & $\begin{array}{l}\mathrm{pH} 4.6 \\
\text { soluble } \\
\text { protein }\end{array}$ & $\begin{array}{l}\mathrm{pH} 4.6 \\
\text { insoluble } \\
\text { protein }\end{array}$ \\
\hline Skim milk powder & NPN & $6.8^{\mathrm{d}}$ & $87.0^{\mathrm{a}}$ \\
Whey powder & $6.2^{\mathrm{b}}$ & $38.7^{\mathrm{a}}$ & $33.0^{\mathrm{d}}$ \\
Buttermilk powders & $28.3^{\mathrm{a}}$ & & \\
BM1 & & $6.9^{\mathrm{d}}$ & $85.5^{\mathrm{a}}$ \\
BM2 & $7.6^{\mathrm{b}}$ & $9.3^{\mathrm{d}}$ & $84.4^{\mathrm{a}}$ \\
BM3 & $6.3^{\mathrm{b}}$ & $14.9^{\mathrm{c}}$ & $78.4^{\mathrm{b}}$ \\
BM4 & $6.7^{\mathrm{b}}$ & $13.9^{\mathrm{c}}$ & $77.2^{\mathrm{b}}$ \\
BM5 & $8.8^{\mathrm{b}}$ & $32.9^{\mathrm{b}}$ & $40.0^{\mathrm{c}}$ \\
\hline
\end{tabular}

${ }^{\mathrm{a}-\mathrm{d}}$ Means within a column not sharing a common superscript differ significantly $(P \leq 0.05)$.

${ }^{1}$ Three buttermilks were obtained from sweet cream (BM1, BM2, and BM3), one was obtained from cultured cream (BM4), and one was obtained from whey cream (BM5). Two buttermilks were commercial (BM1 and BM2), and 3 were manufactured on a pilot-scale (BM3, BM4, and BM5).

${ }^{2}$ Nonprotein nitrogen, soluble protein at $\mathrm{pH} 4.6$, and insoluble protein at $\mathrm{pH} 4.6$ are expressed in \% (wt/ wt) of total nitrogen.

Ash content was between 6 and $8 \%$, and lactose between 43 and 79\%. Differences observed in lactose content were strongly related to the difference in protein content. The ingredients with the low protein levels, WP and whey buttermilk (BM5), were the ones with the highest level of lactose. The $\mathrm{pH}$ of the sweet buttermilks was close to the $\mathrm{pH}$ of skim milk ( $\mathrm{pH} 6.5$ to 6.6 compared with $\mathrm{pH}$ 6.4), whereas the $\mathrm{pH}$ of cultured buttermilk, whey buttermilk, and WP was lower $(\mathrm{pH}<6)$ because of the acidification occurring during the ripening of the cream (for cultured buttermilk) or during the ripening of milk in cheese making (for whey buttermilk and WP). The $\mathrm{pH}$ of the cultured buttermilk was higher than the $\mathrm{pH}$ of ripened cream ( $\mathrm{pH} 5.4$ as compared with $\mathrm{pH} 4.9$ ), because the measurement of the $\mathrm{pH}$ was done in a $4 \%$ protein solution, which had higher buffering capacity compared with a $2 \%$ protein concentration as in the case of cream.

Nitrogen Composition. Table 2 shows the content of the nitrogen fraction for the different powders. Results are expressed as a percentage of the total protein content. Figure 1 illustrates the protein composition of the various powders as obtained by SDS-PAGE.

The NPN fraction (Table 2) represented 6 to $28 \%$ of the total protein content of the powders. It was low in skim milk powder and sweet buttermilk powder ( 6 to $7 \%$ ), and higher in cultured buttermilk (9\%) and whey buttermilk (27 to $28 \%$ ), because of the proteolytic activity of the starter used for cream ripening or cheese making, respectively. The percentage of NPN was especially high in whey buttermilk because of the low TN content (only $14 \%$ on a DM basis compared with $28 \%$ for the cultured buttermilk).

The protein profile as obtained by SDS-PAGE (Figure 1) reveals the lack of caseins in WP and whey butter- milk powder, as expected. The band of whey proteins appears a little fuzzy and with a higher molecular weight in whey powder compared with other powders. This can be attributed to lactosylation of the whey proteins, which occurs during heat treatment of liquid whey and storage of the whey powder and increases the molecular weight of the whey protein (Leonil et al., 1997). Milk fat globule membrane proteins were observed in the sweet, cultured, and whey buttermilks, whereas they were not detected in whey or milk, indicating the presence of MFGM fragment in buttermilks, as reported in previous studies (Corredig and Dalgleish, 1998a; O'Connell and Fox, 2000; Scott et al., 2003).

The protein fraction soluble at $\mathrm{pH} 4.6$ (Table 2) included native whey protein, and some of the MFGM proteins, as the glycoprotein B (also called PAS 6/7; O'Connell and Fox, 2000), which does not precipitate at acidic $\mathrm{pH}$. This fraction was high in whey powder and whey buttermilk (39 and 33\%, respectively) because whey proteins were the major part of the protein in these powders. It constituted a smaller part in skim milk and in sweet and cultured buttermilks, where the major part of the protein was casein, which precipitates at $\mathrm{pH}$ 4.6. However, some differences were noticeable among the 4 buttermilks obtained from milk cream. The 2 buttermilks BM3 and BM4 produced on a pilot scale contained more soluble protein (around 14\%) at $\mathrm{pH} 4.6$ than did the industrial buttermilks, BM1 and BM2 (8 to 9\%). This difference is probably due to the nature of the heat treatment applied to buttermilk before drying. In industry, buttermilk is exposed to severe heat treatment before drying to initiate Maillard reactions and generate browning and flavoring compounds to enhance the sensory properties (Walstra et al., 1999). This severe heat treatment could partly denature the 


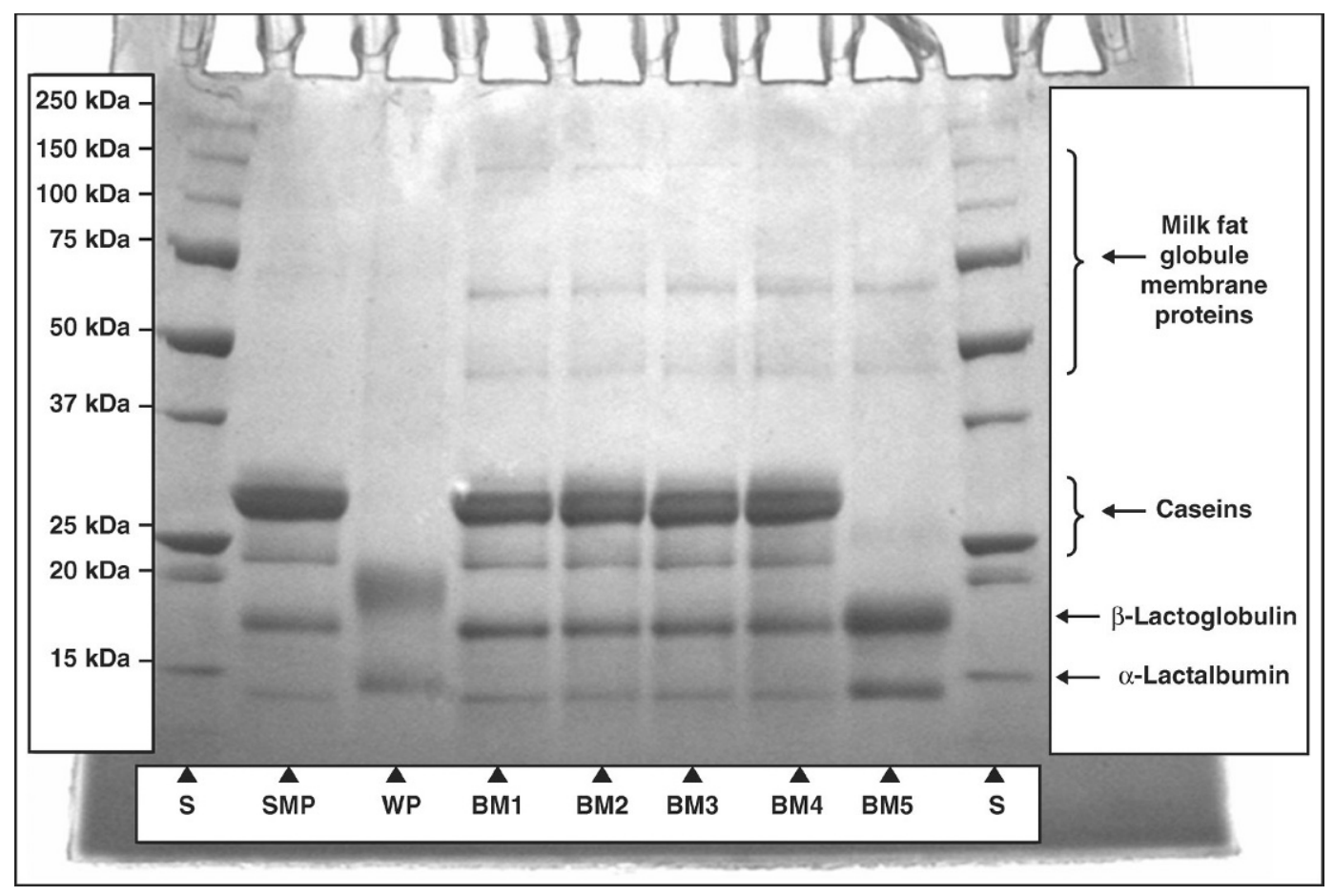

Figure 1. Sodium dodecyl sulfate-PAGE of the various dairy powders. Lanes: $\mathrm{S}=$ molecular weight standard; SMP = commercial skim milk powder; $\mathrm{WP}=$ commercial whey powder; BM1 and BM2 = commercial sweet buttermilk powders; BM3 = pilot-scale sweet buttermilk powder; BM4 = pilot-scale cultured buttermilk powder; and BM5 = pilot-scale whey buttermilk.

whey proteins. When they are denatured, the whey proteins are insoluble at $\mathrm{pH}$ 4.6. For buttermilk manufactured at the DPTC pilot plant, no heat treatment was applied before drying, so no significant denaturation of the whey protein occurred.

The insoluble protein at $\mathrm{pH} 4.6$ (Table 2) represents the casein, some of the MFGM proteins, and the denatured whey protein, which precipitate at an acidic $\mathrm{pH}$. This fraction was high $(>77 \%)$ for skim milk powder and buttermilks from sweet or cultured cream, BM1 to BM4, which contained casein. Surprisingly, although this fraction was only half the amount in the regular and cultured buttermilks, the total insoluble protein was not negligible for whey powder and whey buttermilk (33 to 40\%), which did not contain casein according to results of SDS-PAGE (see Figure 1). One possible explanation is that part of the whey protein of whey and whey buttermilk was denatured during processing. Manufacture of sweet whey powder can involve various processes, including heat treatments (multiple pasteurizations, hot well holding, evaporation, spray drier chamber; Banavara et al., 2003) that denature part of the whey protein. This seems to be the case with our commercial sweet whey powder, because already there is some apparent lactosylation of the whey proteins (see Figure 1), which would prove that the whey has been subjected to high heat treatments. Considering the commercial processing conditions, the whey cream is subjected to a high heat treatment $\left(82^{\circ} \mathrm{C}\right.$ for $\left.45 \mathrm{~s}\right)$ after centrifugation, which may have partly denatured the whey proteins. In addition, whey buttermilk contained a non-negligible fraction of MFGM proteins (see Figure 1 ), which are large proteins insoluble at acidic $\mathrm{pH}$ (O'Connell and Fox, 2000).

\section{Functional Properties}

Protein Solubility. Protein solubility is an important functionality for protein powders, which governs many other functional properties (Kinsella, 1976). Protein solubility of the different powders at various $\mathrm{pH}$ levels is reported in Figure 2.

Protein solubility varied from 12 to $92 \%$ according to the type of dairy powder and the $\mathrm{pH}$ of the solution. The effect on protein solubility of the powder and $\mathrm{pH}$ were both highly significant, as well as the interaction $(P<0.001)$. The protein solubility of the powder was strongly dependent on $\mathrm{pH}$, with lower solubility when $\mathrm{pH}$ was lower than 5 . However, the effect of $\mathrm{pH}$ was much less important for whey powder and whey buttermilk powder. For instance, protein solubility at initial $\mathrm{pH}$ and $\mathrm{pH} 4$ was equal to 92 and $80 \%$, respectively, 


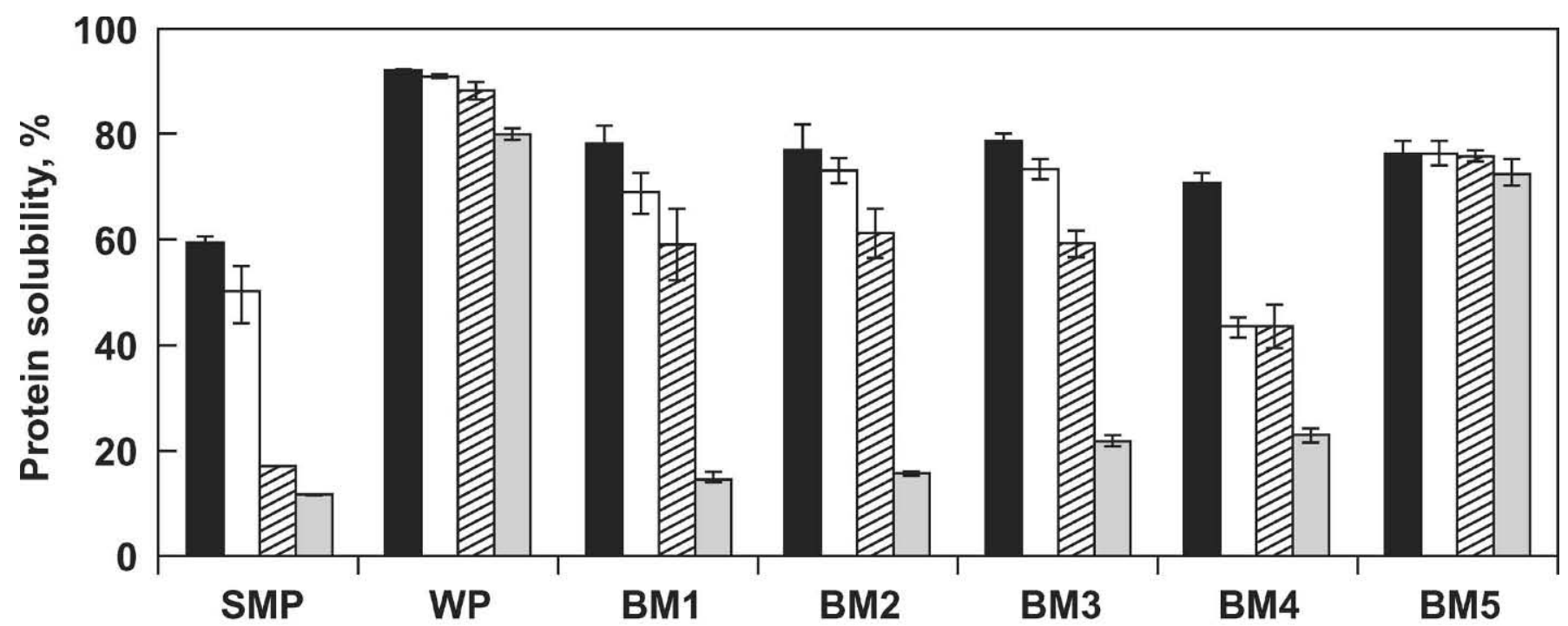

\section{Dairy powder}

Figure 2. Protein solubility determined in a 5\% protein solution of various dairy powders: a commercial skim milk powder (SMP), a commercial whey powder (WP), and 5 buttermilk powders (BM). Three buttermilks were obtained from sweet cream (BM1, BM2, and BM3), one was obtained from cultured cream (BM4), and one was obtained from whey cream (BM5). Two buttermilks were of commercial origin (BM1 and BM2), and 3 were manufactured on a pilot scale (BM3, BM4, and BM5). Measurements were performed at $4 \mathrm{pH}$ values: initial pH (black bar), pH 6 (white bar), pH 5 (diagonal hatch), and pH 4 (shaded). Error bars represent the standard deviations.

for whey powder, and to 77 and $73 \%$, respectively, for whey buttermilk, whereas it decreased from 60 to $79 \%$ to 12 to $23 \%$, respectively, for the other buttermilks and for the skim milk powder. These differences in protein solubility as a function of $\mathrm{pH}$ are due to differences in casein and whey protein contents. Caseins have been shown to be highly insoluble at acidic $\mathrm{pH}$ (where they precipitate), whereas whey protein remains mainly soluble at low $\mathrm{pH}$ (Chobert et al., 1988). Whey powder and whey buttermilks contained no casein, whereas casein represented 77 to $87 \%$ of total protein in sweet and cultured buttermilks as well as skim milk powder (see Table 2).

Viscosity. The flow behavior of the different dairy powders in $4 \%$ protein solution has been studied; the viscosity results determined at $50 \mathrm{~s}^{-1}$ at $4 \mathrm{pH}$ levels are illustrated in Figure 3.

The effects of the dairy powder and $\mathrm{pH}$ as well as their interaction were highly significant $(P<0.001)$. The protein solutions containing casein (solution of skim milk powder and sweet and cultured buttermilks) exhibited a drastic increase in viscosity (3 to 4 times increase) at $\mathrm{pH} 4$ compared with initial $\mathrm{pH}$. This change in viscosity was due to the precipitation of the $\mathrm{pH} 4.6$ insoluble protein fraction at low $\mathrm{pH}$, which represented about $80 \%$ of the total protein fraction. The precipitation of this fraction created a thickening of the solution. On the other hand, the viscosity of the protein solution of whey powder and whey buttermilk, devoid of casein, remained remarkably stable in the $\mathrm{pH}$ range studied. This may be due to the lower content of the insoluble protein fraction in these powders at low $\mathrm{pH}$, where it is only half of the amount of the buttermilk powders (e.g., BM5 has 40\% insoluble protein compared with $\mathrm{BM} 1$, which has $85.5 \%$ ). When compared at initial $\mathrm{pH}$, the viscosity range of the 5 buttermilks was in the order: BM1 = BM2 < BM3 < BM4 = BM5. These differences are due to various factors; 1 ) the fat content, higher for the buttermilks produced on site (BM3, BM4, BM5) than commercial buttermilks (BM1 and BM2); 2) the $\mathrm{DM}$ content, higher for the $4 \%$ protein solution of whey buttermilk BM5 than for other buttermilks, respectively $35 \%$ compared with 15 to $18 \%$, because the protein content of whey buttermilk BM5 was the lowest (see Table 1); and 3) the presence of cells and microbial exopolysaccharide in the solution of buttermilk BM4, ripened with a culture of Flora Danica.

Emulsifying Properties. The volume particle diameter size distribution in $20 \%$ oil in water emulsion has been determined with $2 \%$ protein solution at various $\mathrm{pH}$ levels for the 7 dairy powders. The arithmetic mean for the size of the fat globules is reported in Figure 4.

There was a significant effect $(P<0.001)$ of the type of dairy powder and the $\mathrm{pH}$ of the solution, as well as the interaction, on the size of the globules. For skim milk powder and sweet or cultured buttermilk powders 


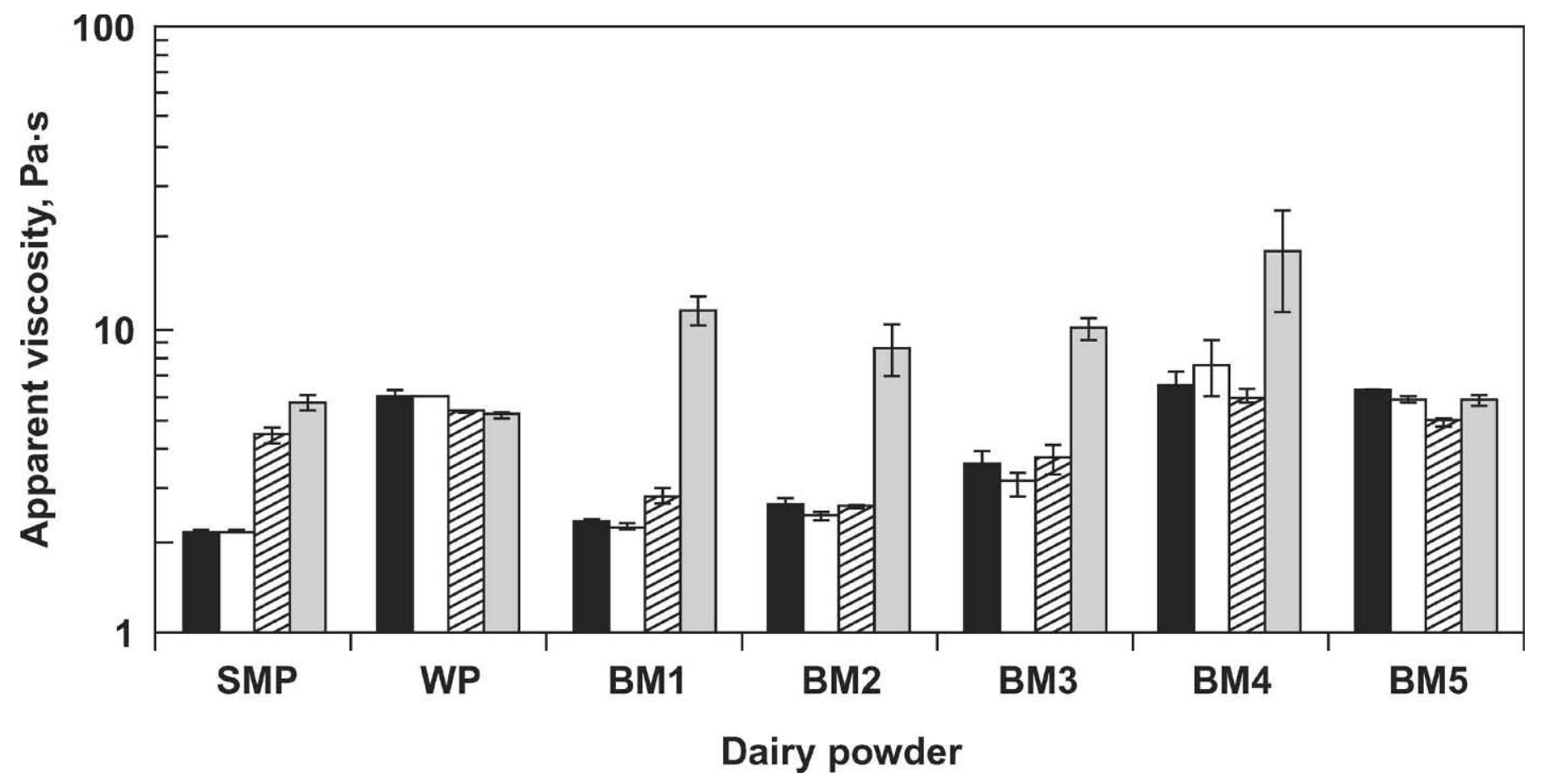

Figure 3. Apparent viscosity determined at a shear rate of $50 \mathrm{~s}^{-1}$ in a $4 \%$ protein solution of various dairy powders: a commercial skim milk powder (SMP), a commercial whey powder (WP), and 5 buttermilk powders (BM). Three buttermilks were obtained from sweet cream (BM1, BM2, and BM3), one was obtained from cultured cream (BM4), and one was obtained from whey cream (BM5). Two buttermilks were of commercial origin (BM1 and BM2), and 3 were manufactured on a pilot scale (BM3, BM4, and BM5). Measurements were performed at $4 \mathrm{pH}$ values: initial $\mathrm{pH}$ (black bar), $\mathrm{pH} 6$ (white bar), $\mathrm{pH} 5$ (diagonal hatch), and $\mathrm{pH} 4$ (shaded). Error bars represent the standard deviations.

(BM1, BM2, BM3, BM4), the $\mathrm{pH}$ had a strong effect on the average globule size, which is 50 to $300 \%$ higher when the $\mathrm{pH}$ is lower than 5 . On the other hand, there was no effect of $\mathrm{pH}$ on globule size when protein solution is obtained from whey powder or whey buttermilk. This lack of effect of $\mathrm{pH}$ on the emulsifying capacity of the whey protein has been reported in the work of Chobert et al. (1988). It can be attributed again to the low level of insoluble protein at $\mathrm{pH} 4.6$ in whey protein powder. In our case, the insoluble protein fraction represented less than $40 \%$ for whey powder and whey buttermilk, and represented about $80 \%$ for skim milk and sweet and cultured buttermilks.

Furthermore, the size of the fat droplet was significantly different $(P<0.05)$ between SMP and sweet or cultured buttermilk (BM1, BM2, BM3, BM4), and between WP and whey buttermilk (BM5). Figure 5 illustrates the distribution of the fat globules at $\mathrm{pH} 6$ for skim milk, whey, buttermilk (sweet and sour), and whey buttermilk. The globule size was 7 to $8 \mu \mathrm{m}$ with sweet and cultured buttermilks compared with $10 \mu \mathrm{m}$ with skim milk, and $5.5 \mu \mathrm{m}$ for whey buttermilk compared with $9.7 \mu \mathrm{m}$ with whey. One of the major differences in composition for sweet and cultured buttermilk vs. skim milk, or for whey buttermilk vs. whey, was the presence of MFGM fractions, as evidenced by the presence of MFGM proteins in the SDS-PAGE of the powders (See Figure 1). Milk fat globule membrane fractions have been shown to have a strong emulsifying capacity (Kanno, 1989). This can probably explain the better emulsifying capacity of whey buttermilk compared with whey, and sweet or cultured buttermilk compared with skim milk. Furthermore, at $\mathrm{pH}>5$, the size of the fat globules was significantly different $(P<0.05)$ between the various buttermilks. The range was BM5 $<$ BM4 < BM1, BM2, and BM3. The whey buttermilk BM5 had lower protein content compared with sweet (BM1, BM2, BM3) or cultured buttermilk (BM4) (14 vs. $\sim 30 \%$; Table 1). However, the phospholipids content was the same in sweet and whey buttermilks, about $1.2 \%$ (Table 1). Consequently, the proportion of phospholipids to protein content was higher for whey buttermilk compared with sweet buttermilk, around 13 and $4 \%$, respectively. In protein solutions used to prepare the emulsions, the phospholipid concentration was higher for whey buttermilk solution than for sweet buttermilk, which could enhance its emulsion capacity. These results are similar to those obtained by Roesch et al. (2004) with buttermilk concentrates and MFGM isolates. Those authors investigated the emulsifying 


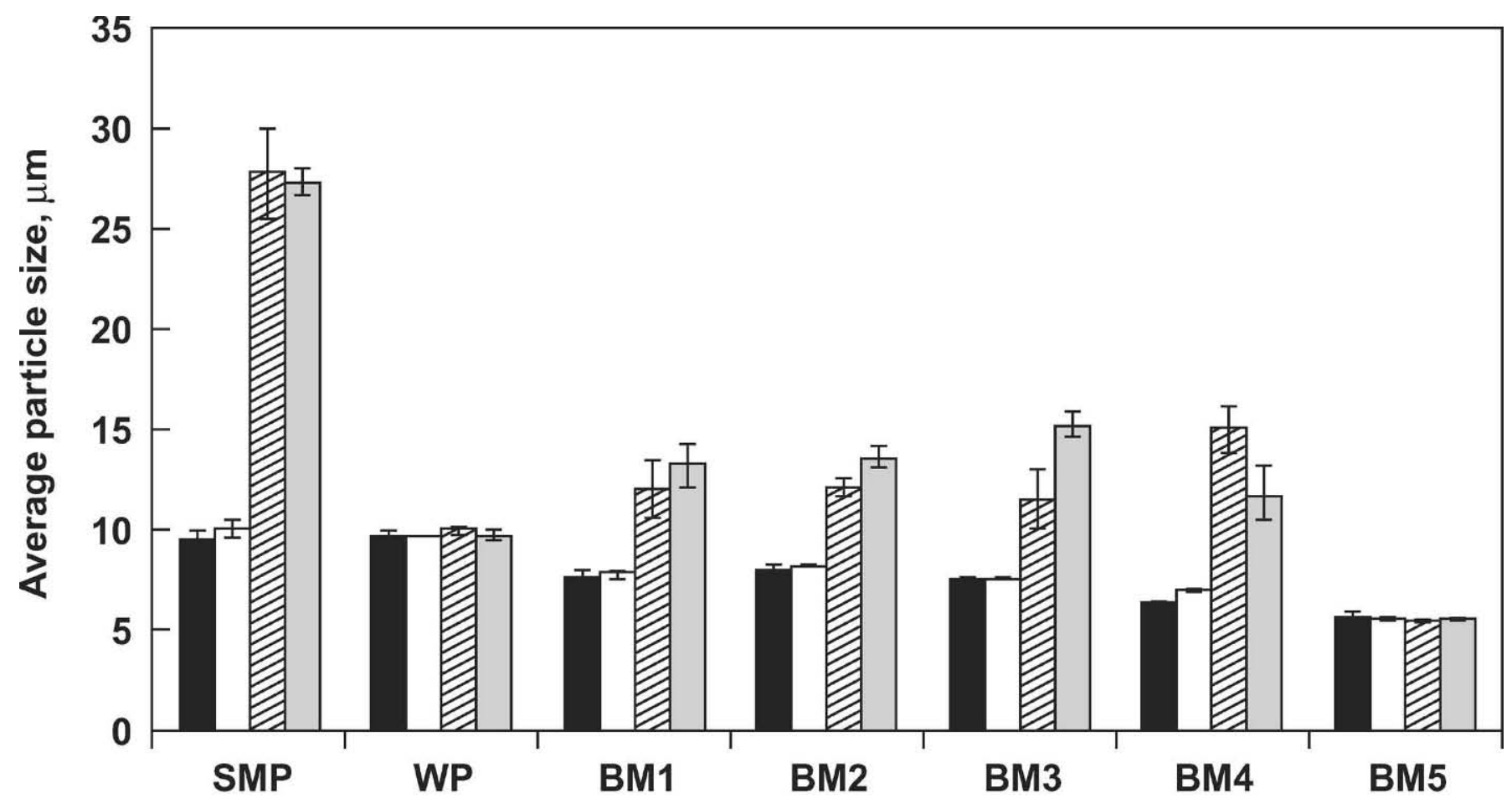

Dairy powder

Figure 4. Average particle size of $20 \%$ (vol/vol) oil in water emulsions stabilized by $2 \%$ protein solution of various dairy powders: a commercial skim milk powder (SMP), a commercial whey powder (WP), and 5 buttermilk powders (BM). Three buttermilks were obtained from sweet cream (BM1, BM2, and BM3), one was obtained from cultured cream (BM4), and one was obtained from whey cream (BM5). Two buttermilks were of commercial origin (BM1 and BM2), and 3 were manufactured on a pilot scale (BM3, BM4, and BM5). Measurements were performed at $4 \mathrm{pH}$ values: initial $\mathrm{pH}$ (black bar), $\mathrm{pH} 6$ (white bar), $\mathrm{pH} 5$ (diagonal hatch), and pH 4 (shaded). Error bars represent the standard deviations.

properties of fractions prepared from commercial buttermilks by microfiltration with or without citrate. When microfiltration was carried out with citrate, casein was dissociated and retentates contained a high amount of MFGM fractions. The resulting MFGM isolates are devoid of casein, but rich in $\beta$-lactoglobulin because of the heat induced protein-protein interactions occurring during the processing of butter. In these fractions, the original ratio of protein in buttermilk (casein, whey protein, and MFGM proteins) was modified. On the other hand, when microfiltration was operated without citrate, this ratio was maintained and the retentate constituted buttermilk concentrate. The study demonstrated better emulsion properties for MFGM isolates than for buttermilk concentrates, and this result was attributed to the higher ratio of MFGM fraction to protein in MFGM isolates as compared with buttermilk concentrates. In our study, the same tendency was observed in a different system, composed of whey buttermilk and regular buttermilk, the former devoid of casein and with a higher ratio of MFGM fraction to protein compared with the latter. Finally, the bacteria and fermentation by-products contained in cultured buttermilk may play a positive role in emulsification and explain the smaller size of the fat globules in emulsion with cultured buttermilk BM4, compared with the one with sweet buttermilk BM1, BM2, and BM3.

Thus, for emulsifying properties, the size of the fat globule in oil in water emulsion was smaller when buttermilk was used (sour, sweet, or whey buttermilk) compared with skim milk or whey. Furthermore, because of the lack of sensitivity of the whey protein to $\mathrm{pH}$, there was no instability of the emulsion at acidic $\mathrm{pH}$ when whey buttermilk was used, whereas sweet or cultured buttermilk lost their emulsifying capacity at $\mathrm{pH}$ 5 or $\mathrm{pH} 4$. Consequently, whey buttermilk offers an interesting alternative to create an emulsion for the formulation of low $\mathrm{pH}$ foods.

Foaming Properties. The foaming capacity of the various dairy powders has been determined in $4 \%$ protein solution and is reported in Figure 6.

The effect of the type of dairy powder, as well as the effect of the $\mathrm{pH}$ and the interaction, were highly significant $(P<0.001)$. The range of foaming capacity 


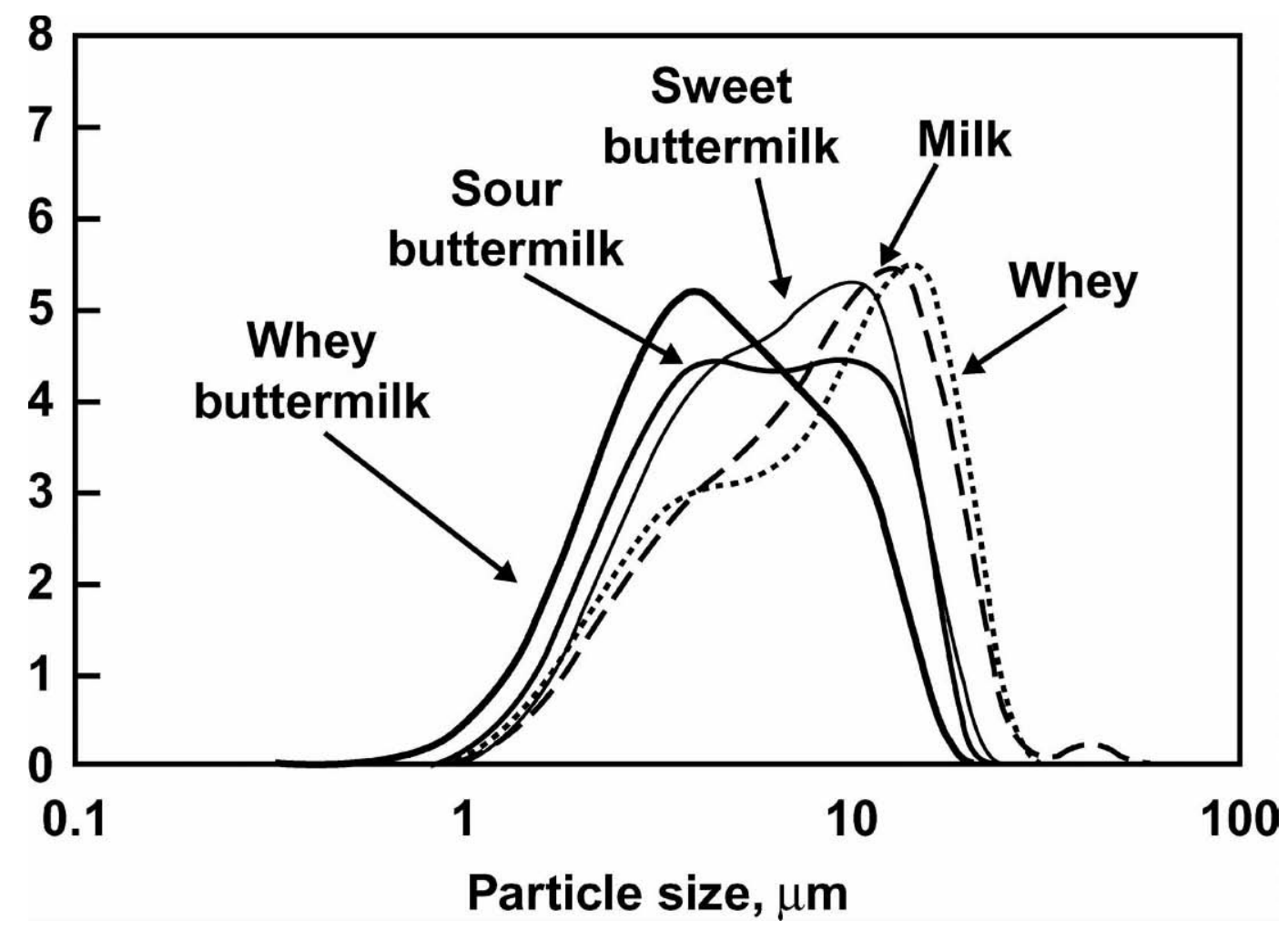

Figure 5. Particle size distribution of $20 \%$ (vol/vol) oil in water emulsions stabilized by a $2 \%$ protein solution at $\mathrm{pH} 6$ of various dairy powders: a commercial skim milk powder (milk), a commercial whey powder (whey), and 3 buttermilk powders. Buttermilks were respectively obtained from sweet cream (sweet buttermilk), cultured cream (sour buttermilk), and whey cream (whey buttermilk), and manufactured at a pilot scale level.

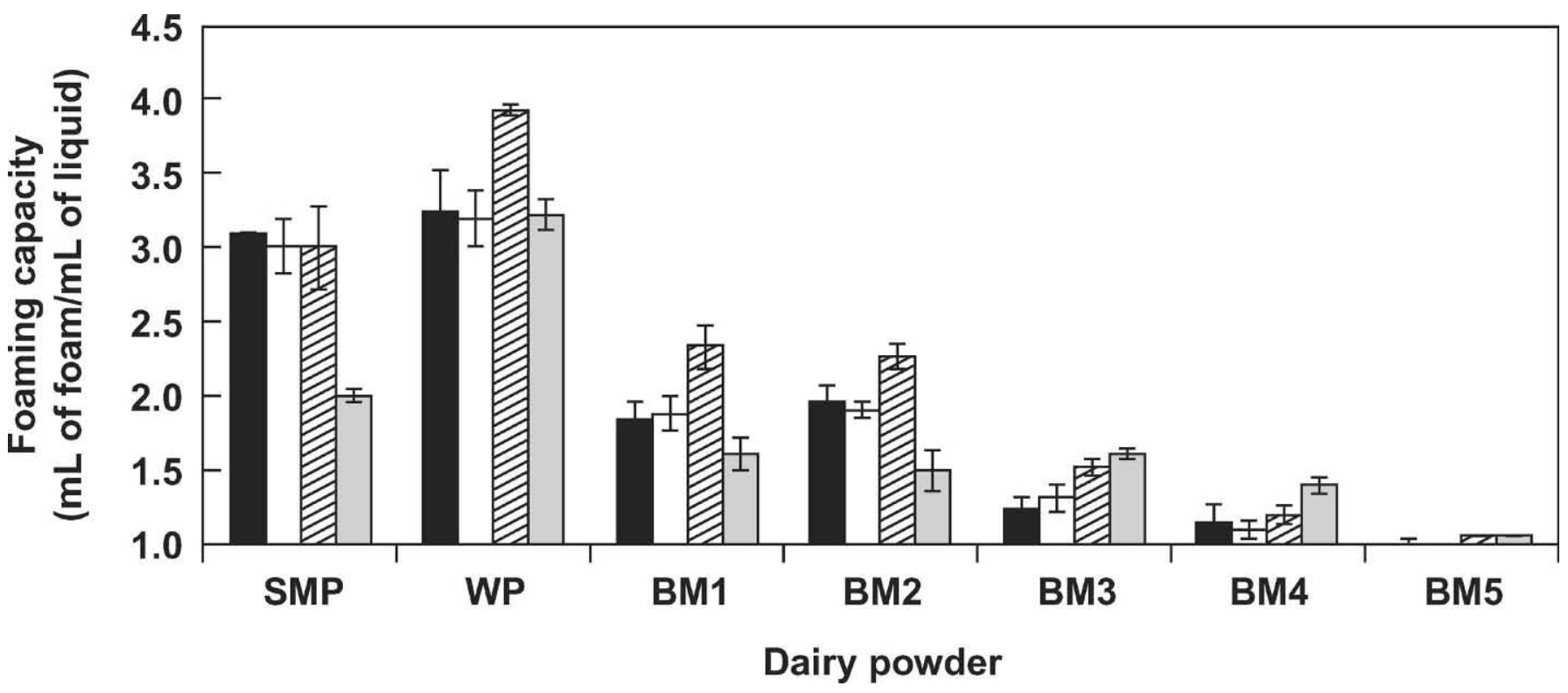

Figure 6. Foaming capacity determined in a $2 \%$ protein solution of various dairy powders: a commercial skim milk powder (SMP), a commercial whey powder (WP), and 5 buttermilk powders (BM). Three buttermilks were obtained from sweet cream (BM1, BM2, and BM3), one was obtained from cultured cream (BM4), and one was obtained from whey cream (BM5). Two buttermilks were of commercial origin (BM1 and BM2), and 3 were manufactured on a pilot scale (BM3, BM4, and BM5). Measurements were performed at $4 \mathrm{pH}$ values: initial $\mathrm{pH}$ (black bar), $\mathrm{pH} 6$ (white bar), $\mathrm{pH} 5$ (diagonal hatch), and pH 4 (shaded). Error bars represent the standard deviations. 
was $\mathrm{BM} 5 \leq \mathrm{BM} 4 \leq \mathrm{BM} 3<\mathrm{BM} 1=\mathrm{BM} 2<\mathrm{SMP}<\mathrm{WP}$. The data were similar for the foaming stability and are not reported in this manuscript. Buttermilks in general had much lower foaming capacity than skim milk or whey powder, with 1.5 to $2.5 \mathrm{~mL}$ of foam per $\mathrm{mL}$ of liquid, compared with 2 to $4 \mathrm{~mL} / \mathrm{mL}$ for skim milk and whey, as reported in the study of Wong and Kitts (2003). This finding can be attributed to the increase of phospholipid concentration in buttermilk by a concentration factor of 4 to 7 (Christie et al., 1987; Elling et al., 1996), which directly affects the foaming capacity by competitive displacement of the protein from the surface by the surfactant (Coke et al., 1990; Vaghela and Kilara, 1996). Among the various buttermilks, pilot-scale-produced buttermilks (BM3, BM4, and BM5) exhibited lower foaming capacity than did commercial buttermilks (BM1 and BM2). This could be attributed to their higher fat content ( 13 to $22 \%$ vs. 6 to $7 \%$, respectively; Table 1). Fats are known to decrease the foaming ability of the protein solution, because of their amphiphilic nature and their ability to displace the protein from the surface (Vaghela and Kilara, 1996). Finally, among the pilot-scale-produced buttermilks, the whey buttermilk (BM5) is the one that exhibited the lowest foaming capacity. It could be due to its higher phospholipids to protein ratio compared with sweet buttermilk (Table 1 ), as already discussed in the previous section. This lack of foaming capacity in whey buttermilk makes this new ingredient particularly attractive for some industrial applications, in which foaming is a critical issue.

\section{CONCLUSIONS}

Whey buttermilk showed significant differences in composition and functional properties compared with sweet or cultured buttermilks. The composition of sweet or cultured buttermilk was comparable with that of skim milk, whereas the composition of whey buttermilk was close to that of whey, except for the fat content, which was always higher for buttermilk. This finding is related to the fact that, by definition, buttermilk is the plasma in which the fat globules are dispersed, which is skim milk in case of sweet or cultured cream, and whey in case of whey cream, with the additional MFGM fractions. The functional properties of whey buttermilk were different from sweet and cultured buttermilk. Whey buttermilk exhibited higher emulsification properties and lower foaming ability compared with sweet or cultured buttermilk, possibly because of a higher ratio of phospholipids to protein. On the other hand, whey buttermilk showed stable levels of protein solubility, emulsifying capacity, and viscosity over a $\mathrm{pH}$ range of 4 to 6 , whereas sweet or cultured buttermilks, rich in casein, had lower solubility and emulsifying capacity, and a higher viscosity at acidic $\mathrm{pH}(\mathrm{pH}<5)$.

Our findings suggest that whey buttermilk could be an interesting and novel dairy ingredient, especially in formulation of low-pH food. However, the sensory properties of whey buttermilk need to be evaluated and compared with commercial buttermilks to ensure its suitability in food formulation. This is the focus of an ongoing study by the authors of this work.

\section{ACKNOWLEDGMENTS}

This work has been funded in part by Dairy Management Inc., the CSU Agricultural Research Initiative, California Dairy Research Foundation, Natural Science and Engineering Research Council of Canada, and Hilmar Cheese Company. The authors thank Lorna Lassonde, Jessica Lee, and Jerry Mattas for their technical assistance.

\section{REFERENCES}

American Dairy Products Institute. 1990. Standards for grades of dry milks, bulletin 916. ADPI, Chicago, IL.

Association of Official Analytical Chemists. 1995. Official Methods of Analysis. 16th ed. AOAC, Gaithersburg, MD.

Astaire, J. C., R. Ward, J. B. German, and R. Jimenez-Flores. 2003. Concentration of polar MFGM lipids from buttermilk by microfiltration and supercritical fluid extraction. J. Dairy Sci. 86:2297-2307.

Banavara, D. S., D. Anupama, and S. A. Rankin. 2003. Studies on physicochemical and functional properties of commercial sweet whey powders. J. Dairy Sci. 86:3866-3875.

Chandan, R. 1997. Dairy-based ingredients. Eagan Press, St. Paul, $\mathrm{MN}$.

Chobert, J. M., C. Bertrand-Harb, and M. G. Nicolas. 1988. Solubility and emulsifying properties of caseins and whey proteins modified enzymatically by trypsin. J. Agric. Food Chem. 36:883-892.

Christie, W. W., R. C. Noble, and G. Davies. 1987. Phospholipids in milk and dairy products. J. Soc. Dairy Technol. 40:10-12.

Coke, M., P. J. Wilde, E. J. Russel, and D. C. Clarck. 1990. The influence of surface composition and molecular diffusion on the stability of foams formed from protein/surfactants mixtures. J. Colloid. Interface Sci. 138:489-503.

Corredig, M., and D. G. Dalgleish. 1997. Isolates from industrial buttermilk: emulsifying properties of materials derived from the milk fat globule membrane. J. Agric. Food Chem. 45:4595-4600.

Corredig, M., and D. G. Dalgleish. 1998a. Buttermilk properties in emulsions with soybean oil as affected by fat globule. J. Food Sci. 63:476-480.

Corredig, M., and D. G. Dalgleish. 1998b. Effect of heating of cream on the properties of milk fat globule membrane isolates. J. Agric. Food Chem. 46:2533-2540.

Corredig, M., R. R. Roesch, and D. G. Dalgleish. 2003. Production of a novel ingredient from buttermilk. J. Dairy Sci. 86:2744-2750.

Dillehay, D. L., S. J. Webb, E. M. Schmelz, and A. H. Merill. 1994. Dietary sphingomyelin inhibits 1,2-dimethylhydrazine-induced colon cancer in CF1 mice. J. Nutr. 124:615-620.

Elling, J. L., S. E. Duncan, T. W. Keenan, W. N. Eigel, and J. Boling. 1996. Composition and microscopy of reformulated creams from reduced-cholesterol butteroil. J. Food Sci. 61:48-53.

Flanagan, J., and R. J. Fitzgerald. 2002. Functionality of Bacillus proteinase hydrolysates of sodium caseinate. Int. Dairy J. 12:737-748.

Guzman-Gonzalez, M., F. Morais, M. Ramos, and L. Amigo. 1999. Influence of skimmed milk concentrate replacement by dry dairy 
products in a low fat set-type yoghurt model system. I: Use of whey protein concentrates, milk protein concentrates and skimmed milk powder. J. Sci. Food Agric. 79:1117-1122.

Hall, G. M. 1996. Methods of testing protein functionality. Blackie Academic and Professional, London, UK.

International Dairy Federation. 2002. World Dairy Situation. FILIDF, Brussels, Belgium.

International Dairy Foods Association. 2003. Milk facts. IDFA, Washington, DC.

Joshi, N. S., P. N. Thakar, and A. H. Jana. 1994. Utilization of buttermilk in cheese making: A review. Indian Food Packer 48:59-65.

Kanno, C. 1989. Emulsifying properties of bovine milk fat globule membrane in milk fat emulsion: Condition for the reconstitution of fat globules. J. Food Sci. 54:1534-1539.

Kinsella, J. E. 1976. Functional properties of proteins in foods: A survey. CRC Crit. Rev. Food Sci. Nutr. 7:219-280.

Leonil, J., D. Molle, J. Fauquant, J. L. Maubois, R. J. Pearce, and S. Bouhallab. 1997. Characterization by ionization mass spectrometry of lactosyl $\beta$-lactoglobulin conjugates formed during heat treatment of milk and whey and identification of one lactosebinding site. J. Dairy Sci. 80:2270-2281.

Marshall, R. T. 1992. Standards methods for the examination of dairy products, 16th Ed. The American Public Health Association Inc., Washington, DC

McCrae, C. H. 1999. Heat stability of milk emulsions: Phospholipidprotein interactions. Int. Dairy J. 9:227-231.

Michalski, M. C., V. Briard, and F. Michel. 2001. Optical parameters of milk fat globules for laser light scattering measurements. Lait 81:787-796.

Morin, P., R. Jiménez-Flores, and Y. Pouliot. 2004. Effect of temperature and pore size on the fractionation of fresh and reconstituted buttermilk by microfiltration. J. Dairy Sci. 87:267-273.

Morin, P., Y. Pouliot and R. Jiménez-Flores. A comparative study of the fractionation of regular buttermilk and whey buttermilk by microfiltration. J. Food Eng. doi:10.1016/j.jfoodeng.2005.06.065

Mulder, H., and P. Walstra. 1974. The milk fat globule. Centre for Agricultural Publishing and Documentation, Wageningen, The Netherlands.

National Agricultural Statistics Service. 2004. Dairy products, 2003 Summary. USDA, Washington, DC

O'Connell, J. E., and P. F. Fox. 2000. Heat stability of buttermilk. J. Dairy Sci. 83:1728-1732.

Raval, D. M., and V. V. Mistry. 1999. Application of ultrafiltered sweet buttermilk in the manufacture of reduced fat process cheese. J. Dairy Sci. 82:2334-2343.

Raymundo, A., J. M. Franco, J. Empis, and I. Sousa. 2002. Optimization of the composition of low-fat oil-in-water emulsions stabilized by white lupin protein. J. Am. Oil Chem. Soc. 79:783-790.

Roesch, R. R., A. Rincon, and M. Corredig. 2004. Emulsifying properties of fractions prepared from commercial buttermilk by microfiltration. J. Dairy Sci. 87:4080-4087.
Rueda, R., J. L. Sabatel, J. Maldonado, J. S. Molina-Font, and A. Gil. 1998. Addition of gangliosides to an adapted milk formula modifies levels of fecal Escherichia coli in preterm newborn infants. J. Pediatr. 133:90-94.

Sachdeva, S., and W. Buchheim. 1997. Recovery of phospholipids from buttermilk using membrane processing. Kieler Milchw. Forsch. 49:47-68.

Schmelz, E. M., D. L. Dillehay, S. K. Webb, A. Reiter, J. Adams, and A. H. Merill. 1996. Sphingomyelin consumption supresses aberrant colonic crypt foci and increases the proportion of adenomas versus adenocarcinomas in CF1 mice treated with 1,2-dimethylhydrazine: Implications for dietary sphingolipids and colon carcinogenis. Cancer Res. 56:4936-4941.

Schmelz, E. M., M. A. Dombrink-Kurtzman, P. C. Roberts, Y. Kozutsumi, T. Kawasaki, and A. H. Merill. 1998. Induction of apoptosis by fumosinin B1 in HT-29 cells is mediated by the accumulation of endogenous free sphingoid bases. Toxicol. Appl. Pharmacol. 148:252-260.

Scott, L. L., S. E. Duncan, S. S. Sumner, K. M. Waterman, and K. E. Kaylegian. 2003. Influence of emulsifying component composition on creams formulated with fractionated milkfat. J. Agric. Food Chem. 51:5933-5940.

Singh, H., and R. P. Tokley. 1990. Effects of preheat treatments and buttermilk addition on the seasonal variations in the heat stability of recombined evaporated milk and reconstituted concentrated milk. Aust. J. Dairy Technol. 45:10-16.

Sprong, R. C., M. F. E. Hulstein, and R. van der Meer. 2002. Bovine milk fat components inhibit food-borne pathogens. Int. Dairy J. 12:209-215.

Surel, O., and M. H. Famelart. 1995. Ability of ceramic membranes to reject lipids of dairy products. Aust. J. Dairy Technol. 50:36-40.

Trachoo, N., and V. V. Mistry. 1998. Application of ultrafiltered sweet buttermilk and sweet buttermilk powder in the manufacture of nonfat and low fat yogurts. J. Dairy Sci. 81:3163-3171.

Turcot, S., S. L. Turgeon, and D. St-Gelais. 2001. Effect of buttermilk phospholipid concentrations in cheese milk on production and composition of low fat Cheddar cheese. Lait 81:429-442.

Vaghela, M. N., and A. Kilara. 1996. Foaming and emulsifying properties of whey protein concentrates as affected by lipid composition. J. Food Sci. 61:275-280.

Vetter, J. L. 1984. Dairy products for the cereal processing industry. American Association of Cereal Chemists, Inc., St. Paul, MN.

Walstra, P., T. J. Geurts, A. Noomen, A. Jellema, and M. A. J. S. van Boekel. 1999. Dairy Technology: Principles of milk properties and processes. Marcel Dekker, New York, NY.

Wong, P. Y. Y., and D. D. Kitts. 2003. A comparison of the butter milk solids functional properties to nonfat dried milk, soy protein isolate, dried egg white, and egg yolk powders. J. Dairy Sci. $86: 746-754$ 